\title{
Longitudinal study of the reasons for the reluctance of students of the Faculty of Physical Education for Men Joined Alexandria University majoring in sports administration
}

\section{Barakat Faraj Mohammed Ezz Al-Arab}

Lecture, sports administration \& recreation, faculty of physical education for men, Alexandria University, Egypt

\section{Introduction}

The global educational field technique and a great revolution in the information era has become a motto of knowledge production and research between the folds to achieve excellence for the advancement of individuals and communities. (18)

It is therefore essential that this aspect has the utmost importance in terms of spending and policies based on clear strategies. (12: 155)

That it could develop education system through educational institutions management style of modern management in terms of capacity and efficiency with accountability and measure results and strengthen the decentralization of the learning management system‘Under the separation of educational processes and divergence from the requirements of the labor market developments and the needs of business sectors, organizations and services of skilled human resources and capacity commensurate with the technical condition of the superior prevailing in most of the sectors which are not matched by the curriculum and the content of courses in institutions of higher education. (9:13)

It seeks faculties of Physical Education for the development of its staff capabilities of the students it seeks to prepare leaders and members of specialists able to lead actors youth to achieve success in their $d$ at the same time have the ability to help others and teach them and train them so that permeated the expected benefits of the practice or study of the different sports activities. (7)

Refers noted that the demand for action sports management has significantly increased in recent times and perhaps it was a result of what went to him some of the faculties of Physical Education in Egypt Duplication sections to study sports management and it is certain that all of this has come to meet the requirements and needs of the labor market where this has become the market absorb large numbers of graduates of Physical Education to work in the sports bodies, and despite the fact that leadership talent is one of the administrative work requirements in the field of sports, but the refinement and rehabilitation and study is one of the importance of what was to refine this talent than we can say with him to study sports management is essential to achieve success in the administrative work of any area in which the incident. (8:35)

Sports management and is one of the important science in recent times because of their active role in raising the efficiency of institutions in terms of administration, whether internal or external, as well as economically by increasing its resources through marketing, investment or care and other rights of modern management 
methods which are used in the development of enterprise resources, as well as the role of effective management through human resources management by the selection and appointment, promotion and the development of incentives and salaries, description and characterization of the job and that use scientific manner talk to elevate the level of the enterprise and all these and other factors indicate the importance of management in recent times.

Through the work of the researcher as a member of the faculty of Sports Management Department reduced the number of students applying for admission to the specialization of administration compared Pt khassa teaching and training has noted that for a long time, as shown in form (1) and through the analysis of the results of studies numbers (1) (2) (4) (5) (13) (14) (15) (17) (19), which describes the importance of addressing this study, so the researcher tried to identify the reasons for the reluctance of students Joined.

The form of (1) put the relationship between the numbers of students in college majors

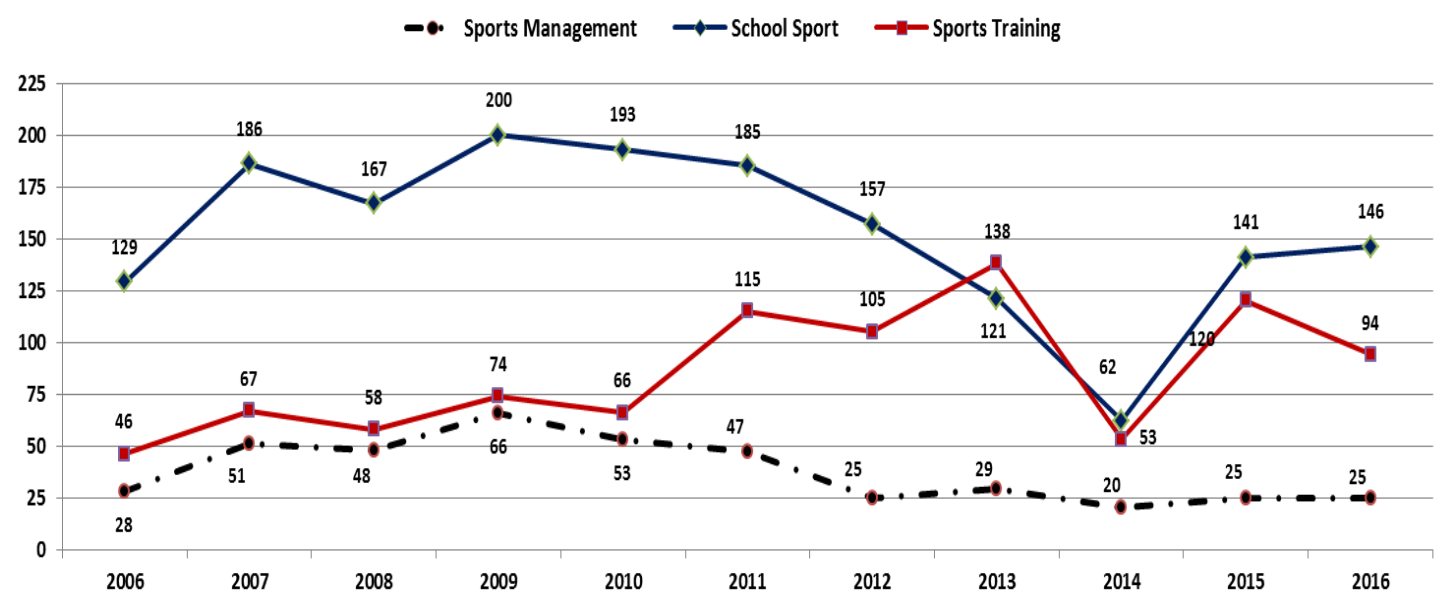

\section{Objective of the study}

The study aims to identify the reasons for the reluctance of students of the Faculty of Physical Education for Men Joined Alexandria University majoring in sports management.

\section{The study questions}

1. What are the reasons for the reluctance of students of the Faculty of Physical Education for Men Joined Alexandria University majoring in sports management?

2. Are there differences in the reasons for the reluctance between the first and second baseline study?

\section{The study measures:}

Methodology: Using researcher descriptive method survey manner

Table (1) Classification and distribution of the study sample

\begin{tabular}{l||l||c}
\hline \hline Charactoninativir & first study & Second study \\
\hline
\end{tabular}




\begin{tabular}{l|c|c|c}
\hline \multicolumn{1}{c|}{} & $\begin{array}{c}\text { Scoping study } \\
\text { essential }\end{array}$ & & \\
\hline Training sport specialty & 17 & 52 & 42 \\
\hline \hline school sport Specialty & 13 & 42 & 50 \\
\hline \hline total & 30 & 94 & 92 \\
\hline \hline
\end{tabular}

\section{The means of data collection}

Researcher uses the questionnaire and personal interview for data collection.

\section{The scoping study}

The researcher conducted a prospective study on a sample of (30) students were chosen randomly from the original community and the way out of the core sample study.

\section{Scientific transactions of the questionnaire}

\section{First: Honesty is the expense of two ways}

A. Believe content (the arbitrators): Depend researcher in the sincerity of the survey of the sincerity of the arbitrators and the number of (5) arbitrators in order to identify the extent appropriate themes and phrases and the clarity of phrases The researcher has embraced the proportion of $80 \%$ agreement.

B. sincerity of internal consistency: the sincerity of internal consistency through the correlation coefficients between the ferry and the total number of the axis to which they belong after deleting the phrase degree account ranging value between ( 0.309 to 0.737 ) to the first axis, $(0.420$ to 0.738$)$ to the second axis, ( 0.338 to 0.793$)$ to the third axis

Second: Stability account by the values of (alpha coefficient for Kronbak)

The researcher after the amendments made by the expert application questionnaire form on a sample of (30) students were chosen randomly from the original community of the academic year in 2013 and way beyond basic sample study, in order to legalize statistical form under Aldrich, It has been deleted phrases to affect the validity and reliability of the form, ranging value of alpha coefficient for Kronbak between $(0.808$ to 0.922 )

\section{Application study}

The researcher first application of the basic study on a sample study of students in the 2013 academic year, and the second study on a sample study of students in the academic year 2015.

\section{Statistical treatments}

Almioah- ratio coefficient alpha coefficient Runback-the interior consistency square

Kai- Mann-Whitney test

\section{Results View and discuss}

Table (2) Percentage of statistical and semantic own responses to the first axis: factors related to the student

\begin{tabular}{|l|l|l|l|l|l|l|l|l|l|}
\hline \multirow{2}{*}{ N } & \multicolumn{4}{|c|}{ First basic study=94 } & \multicolumn{3}{|c|}{ second basic study n=92 } & \multicolumn{2}{|c|}{$\begin{array}{l}\text { Mann-Whitney test for } \\
\text { comparison between the } \\
\text { two studies }\end{array}$} \\
\cline { 2 - 8 } & $\begin{array}{l}\text { Chi- } \\
\text { square }\end{array}$ & $\begin{array}{c}\text { Approv } \\
\text { al rate } \\
\%\end{array}$ & $\begin{array}{c}\text { Arrange } \\
\text { ment }\end{array}$ & Chi-square & $\begin{array}{l}\text { Approva } \\
\text { 1 rate } \\
\%\end{array}$ & $\begin{array}{l}\text { larrange } \\
\text { ment }\end{array}$ & Z Value & $\begin{array}{l}\text { Significant } \\
\text { level }\end{array}$ \\
\hline
\end{tabular}




\begin{tabular}{|c|c|c|c|c|c|c|c|c|c|}
\hline $\mathbf{a}$ & Social members & & & & & & & & \\
\hline 1 & $\begin{array}{l}\text { useful lack of specialization } \\
\text { administration }\end{array}$ & $* 8.33$ & 56.38 & 11 & 5.00 & 47.87 & 13 & 1.49 & 0.14 \\
\hline 2 & $\begin{array}{l}\text { Relatives working in a career advice } \\
\text { within the scope of } \\
\text { (training, teaching) }\end{array}$ & $* 28.98$ & 70.74 & 2 & $* 52.87$ & 77.13 & 1 & 1.49 & 0.14 \\
\hline 3 & $\begin{array}{l}\text { Influenced by the work of one of the } \\
\text { parents in the area of specialization } \\
\text { (training, teaching ) }\end{array}$ & $* 9.28$ & 39.89 & 14 & 2.89 & 49.47 & 12 & 1.53 & 0.13 \\
\hline 4 & $\begin{array}{l}\text { Encouraging family members to join } \\
\text { the specialization (training, teaching )( }\end{array}$ & *12.45 & 61.70 & 8 & $* 31.72$ & 71.81 & 2 & 1.72 & 0.09 \\
\hline B & Economic factors & & & & & & & & \\
\hline 1 & $\begin{array}{l}1 \text { does not provide a return specialization } \\
\text { administration materially rewarding for } \\
\text { employees in which }\end{array}$ & *11.83 & 63.83 & 6 & *19.33 & 64.67 & 3 & 0.00 & 1.00 \\
\hline 2 & $\begin{array}{l}\text { ack the physical benefits of } \\
\text { specialization Administration }\end{array}$ & $* 12.92$ & 62.23 & 7 & 5.30 & 54.35 & 8 & 1.44 & 0.15 \\
\hline 3 & $\begin{array}{l}\text { lack of employment } \\
\text { opportunities associated with the } \\
\text { specialization of Administration }\end{array}$ & $* 26.58$ & 70.74 & 2 & 2.05 & 51.63 & 11 & $* 3.19$ & 0.00 \\
\hline 4 & $\begin{array}{l}\text { does not help the adm inistration to } \\
\text { allocate work in other areas }\end{array}$ & *21.02 & 69.15 & 4 & 3.41 & 56.52 & 7 & $* 2.00$ & 0.05 \\
\hline c & psychological and mental factors & & & & & & & & \\
\hline 1 & $\begin{array}{l}\text { is not commensurate with my abilities } \\
\text { Industry Leaders realizable } 12\end{array}$ & 1.11 & 54.26 & 12 & $* 8.00$ & 59.24 & 5 & 0.97 & 0.33 \\
\hline 2 & $\begin{array}{l}2 \text { does not help allocate administration to } \\
\text { create favorable psychological } \\
\text { atmosphere for students to rush him }\end{array}$ & $* 9.15$ & $\mathbf{5 9 . 5 7}$ & 10 & 1.07 & $\mathbf{5 3 . 8 0}$ & 9 & 1.18 & 0.24 \\
\hline 3 & $\begin{array}{lll}\text { lack of conviction } & \text { advantage } \\
\text { Administration for Industry } & \text { and other } \\
\text { disciplines } & & \\
\end{array}$ & $* 16.68$ & 67.02 & 5 & 1.40 & 53.80 & 9 & $* 2.03$ & 0.04 \\
\hline 4 & $\begin{array}{l}\text { belief that specialty simple } \\
\text { administration does not carry any } \\
\text { thought or after a new scientific }\end{array}$ & 1.23 & 48.94 & 13 & 3.32 & 46.74 & 14 & 0.38 & 0.70 \\
\hline 5 & $\begin{array}{l}\text { inadequate specialization management of } \\
\text { my desires and personal tendencies }\end{array}$ & $* 41.83$ & 75.53 & 1 & $* 11.23$ & 63.04 & 4 & $* 2.27$ & 0.02 \\
\hline 6 & $\begin{array}{l}\text { inadequacy of } \quad \text { specialization } \\
\text { management of my abilities and personal } \\
\text { talents }\end{array}$ & $* 10.90$ & 61.17 & 9 & 2.76 & 57.07 & 6 & 0.73 & 0.47 \\
\hline
\end{tabular}

$*$ Chi-square significant at the 0.05 level $=5.99 *$ significant where the value of $\mathrm{Z}$ spreadsheet at a level of $0.05=1.96$

Seen from the table (2) of the repetitive and the percentage of statistical and semantic own responses to the first axis: factors related to the student

(Study1) the presence of significant differences between the responses except ferries numbers $(1,4) \mathrm{c}$ ranging value of Chi square between $(8.33$ to 41.83$)$ and the moral values at the 0.05 level, and by consent reached between (39.89\% to $75.53 \%$ ) as responses for each level shows the arrangement of the words and phrases illustrated in terms of the approval of the most and least approval.

(Study2) the absence of significant differences between the responses except ferries numbers $(2,4)$ A, 1 (b), (1,5) c ranging value of Chi square between (1.07 to 52.87) and by consent reached between ( $46.74 \%$ to $77.13 \%$ ) also shows the level of responses for each of the words and phrases arrangement illustrated in terms of the approval of the most and least approval.

It is clear from the results emphasize the importance of the role of social, economic, psychological and mental factors in the specialty by the students who are enrolled. 
The results agreed with the results of the study are:Eid Mohammed Kanaan (2010) (6), which emphasizes the importance of the impact of social factors in the participation of female students in school sports activities, Abdul Salam Bo Xian and Mourad Ben Amara (2011) (4) which refers to the importance of social factors in the enrollment of students to specialize Sports, Ahmed Hegana, Walid Shahin (2010) (2) states that the reasons for the reluctance of most students of the Faculty of Physical Education for the practice of sports competitions Arbitration social, economic and psychological factors, Noha Mohammed Mahmoud (2011) (15), which suggests that social and economic factors affecting the reluctance of students to participate in school sports activities.

Table (3) Percentage of statistical and semantic own responses to the second axis: factors related to sports management and recreation department

\begin{tabular}{|c|c|c|c|c|c|c|c|c|c|}
\hline \multirow{2}{*}{$\mathbf{N}$} & \multirow{2}{*}{ Phrase } & \multicolumn{3}{|c|}{ First basic study=94 } & \multicolumn{3}{|c|}{ second basic study } & \multicolumn{2}{|c|}{$\begin{array}{l}\text { Mann-Whitney test for } \\
\text { comparison between the } \\
\text { two studies }\end{array}$} \\
\hline & & $\begin{array}{l}\text { Chi- } \\
\text { square }\end{array}$ & $\begin{array}{l}\text { Approval } \\
\text { rate } \\
\%\end{array}$ & $\begin{array}{c}\text { Arra } \\
\text { ngem } \\
\text { ent }\end{array}$ & Chi-square & $\begin{array}{l}\text { Approva } \\
\text { I rate } \\
\%\end{array}$ & $\begin{array}{c}\text { arrange } \\
\text { ment }\end{array}$ & Z Value & $\begin{array}{c}\text { Significant } \\
\text { level }\end{array}$ \\
\hline $\mathbf{A}$ & \multicolumn{9}{|l|}{ Factors related to faculty members } \\
\hline 1 & $\begin{array}{l}\text { Not motivate students by faculty } \\
\text { members }\end{array}$ & *23.77 & 69.68 & 1 & 2.46 & 45.11 & 3 & *3.86 & 0.00 \\
\hline 2 & $\begin{array}{l}\text { GMT does not adhere to the beginning } \\
\text { and end of the lecture }\end{array}$ & 4.62 & 40.96 & 21 & $* 24.15$ & 28.80 & 21 & 1.97 & 0.05 \\
\hline 3 & $\begin{array}{l}\mathrm{t} \text { does not encourage scientific } \\
\text { discussions }\end{array}$ & 0.45 & 50.00 & 13 & $* 12.29$ & 34.78 & 18 & $* 2.50$ & 0.01 \\
\hline 4 & $\begin{array}{l}\text { Not characterized by the ethics and the } \\
\text { ethics of the profession }\end{array}$ & $* 12.60$ & 35.11 & 22 & $* 29.69$ & 27.17 & 23 & 1.42 & 0.16 \\
\hline 5 & Not just in the Student Assessment & 3.10 & 43.09 & 20 & $* 16.90$ & 32.07 & 20 & 1.77 & 0.08 \\
\hline 6 & $\begin{array}{l}\text { t does not allow enough time for } \\
\text { dialogue and discussion }\end{array}$ & 3.60 & 46.28 & 17 & $* 17.23$ & 34.24 & 19 & *2.16 & 0.03 \\
\hline 7 & $\begin{array}{l}\text { It does not respect the norms and } \\
\text { traditions in university teaching }\end{array}$ & $* 17.38$ & 32.98 & 23 & *25.87 & 28.26 & 22 & 0.99 & 0.32 \\
\hline 8 & Biased in its relations with students & 3.68 & 46.28 & 17 & $* 13.20$ & 35.87 & 17 & $* 2.01$ & 0.04 \\
\hline $\mathbf{B}$ & \multicolumn{9}{|c|}{ courses teaching sports management and recreation department } \\
\hline 1 & $\begin{array}{l}\text { Not scheduled to gain new knowledge } \\
\text { and skills }\end{array}$ & 1.94 & 54.79 & 9 & 5.24 & 41.30 & 5 & $* 2.26$ & 0.02 \\
\hline 2 & $\begin{array}{l}\text { It does not help the book 's decision to } \\
\text { increase achievement }\end{array}$ & 1.55 & 49.47 & 14 & 5.36 & 39.67 & 9 & 1.63 & 0.10 \\
\hline 3 & $\begin{array}{l}\text { There is difficulty in getting books and } \\
\text { references from the library }\end{array}$ & 0.19 & 47.87 & 15 & $* 7.40$ & 37.50 & 15 & 1.69 & 0.09 \\
\hline 4 & Difficult topics decisions Section & 2.83 & 50.53 & 12 & 5.27 & 39.67 & 9 & 1.76 & $\mathbf{0 . 0 8}$ \\
\hline 5 & $\begin{array}{l}\text { Courses not fit with the outside labor } \\
\text { market needs }\end{array}$ & *8.19 & $\mathbf{5 9 . 5 7}$ & 5 & 3.47 & 41.30 & 5 & $* 3.02$ & 0.00 \\
\hline 6 & $\begin{array}{l}\text { Lack of clarity in the respective } \\
\text { decision of the scientific article }\end{array}$ & 2.11 & 53.19 & 10 & *6.90 & 39.13 & 11 & $* 2.26$ & 0.02 \\
\hline 7 & $\begin{array}{l}\text { The similarity of the names and } \\
\text { contents of the oath prescribed } \\
\text { materials }\end{array}$ & *9.74 & 61.70 & 3 & $* 15.36$ & 39.13 & 11 & *3.88 & 0.00 \\
\hline 8 & $\begin{array}{l}\text { Vision and goal of the operation is clear } \\
\text { of Education }\end{array}$ & $* 13.55$ & 65.43 & 2 & *6.36 & 38.04 & 13 & *4.39 & 0.00 \\
\hline 9 & $\begin{array}{l}\text { Lack of conviction of those responsible } \\
\text { for the sports bodies of the importance } \\
\text { of practical education }\end{array}$ & *7.03 & 58.51 & 7 & 2.18 & 42.39 & 4 & $* 2.56$ & 0.01 \\
\hline 10 & $\begin{array}{l}\text { Practical education program does not } \\
\text { meet the aspirations of the student }\end{array}$ & $* 11.51$ & 61.17 & 4 & 1.40 & 47.28 & 2 & $* 2.24$ & 0.02 \\
\hline $\mathbf{C}$ & \multicolumn{9}{|c|}{ Joined Sports Management and Recreation Department } \\
\hline 1 & Admissions department is a clear policy & $* 7.94$ & 59.04 & 6 & 0.47 & 51.09 & 1 & 1.18 & 0.24 \\
\hline 2 & $\begin{array}{l}\text { The difficulty of administrative } \\
\text { procedures for admission to the } \\
\text { department }\end{array}$ & 0.79 & 47.87 & 15 & 3.80 & 40.76 & 7 & 1.00 & 0.32 \\
\hline 3 & $\begin{array}{l}\text { The difficulty of personal interview for } \\
\text { students }\end{array}$ & 2.32 & 43.62 & 19 & $* 14.87$ & 36.41 & 16 & 0.99 & 0.32 \\
\hline
\end{tabular}




\begin{tabular}{|c|c|c|c|c|c|c|c|c|c|}
\hline 4 & $\begin{array}{l}\text { Acceptance specialization policy does } \\
\text { not depend on the student's ability }\end{array}$ & 4.43 & 56.38 & 8 & *7.93 & 40.76 & 7 & $* 2.69$ & 0.01 \\
\hline 5 & $\begin{array}{l}\text { Acceptance specialization policy does } \\
\text { not depend on the wishes of the student }\end{array}$ & 0.53 & 52.66 & 11 & *9.87 & 38.04 & 13 & $* 2.34$ & 0.02 \\
\hline
\end{tabular}

$*$ Chi-square significant at the 0.05 level $=5.99 *$ significant where the value of $\mathrm{Z}$ spreadsheet at a level of $0.05=1.96$

It is seen from the table (3) of the repetitive and the percentage of statistical and semantic own responses to the second axis: factors related to sports management and recreation department

(Study1) the absence of significant differences between the responses except ferries numbers $(1,4,7) \mathrm{A},(5,7,8,9,10) \mathrm{b}, 1$ (c) ranged value of Chi square between $(0.19$ to $13.55)$ and by consent reached between $(32.98 \%$ to $69.68 \%)$ also shows the level of responses for each of the words and phrases arrangement illustrated in terms of the approval of the most and least approval.

(Study2) the presence of significant differences between the responses except with numbers 1 (a), $(1,2,4,5,9,10) \mathrm{b},(1,2) \mathrm{c}$ ranging value of Chi square between $(0.47$ to $29.69)$ and by consent reached between $(27.17 \%$ to $51.09 \%)$ also shows the level of responses for each of the words and phrases arrangement illustrated in terms of the approval of the most and least approval

\section{It is clear from the results these factors do not affect the reluctance of students on school Pt_khas Sports Management.}

And describes the study Ac kgoz (2005) (16) of the characteristics of the teacher and their impact on the direction of students and objectionable qualities in the teacher of the students is the bias in the treatment and cruelty and lack of attention to appearance and loss of control of the desired qualities are justice, equality and calm and good listening to students.

The need to adopt new structures with content of study programs commensurate with the nature of the next phase is based on the development of courses in schools and universities and support educational innovations in the field of education and improves human capital and makes the effort and investment in life-long learning and distance education. (10)

The future engineering education in the Arab world is an urgent need to develop new formulas to draw educational policies take into account the quality of educational curricula and methods of assessment and funding mechanisms and pricing of creativity and employ Arabic language Intelligent than we can grab a respectable position in the higher education market with the need to focus on other cultures and languages. (11:170)

Table (4) Percentage of statistical and semantic own responses third axis: external factors

\begin{tabular}{|c|c|c|c|c|c|c|c|c|c|}
\hline \multirow{2}{*}{$\mathbf{N}$} & \multirow{2}{*}{ Phrase } & \multicolumn{3}{|c|}{ First basic study $=94$} & \multicolumn{2}{|c|}{ second basic study } & \multirow{2}{*}{$\begin{array}{c}\mathbf{n}=92 \\
\begin{array}{c}\text { arrange } \\
\text { ment }\end{array}\end{array}$} & \multicolumn{2}{|c|}{$\begin{array}{l}\text { Mann-Whitney test for } \\
\text { comparison between the } \\
\text { two studies }\end{array}$} \\
\hline & & $\begin{array}{c}\text { Chi- } \\
\text { square }\end{array}$ & $\begin{array}{l}\text { Approval } \\
\text { rate } \\
\%\end{array}$ & $\begin{array}{c}\text { Arra } \\
\text { ngem } \\
\text { ent }\end{array}$ & Chi-square & $\begin{array}{l}\text { Approva } \\
\text { I rate } \\
\%\end{array}$ & & Z Value & $\begin{array}{c}\text { Significant } \\
\text { level }\end{array}$ \\
\hline $\mathbf{A}$ & External labor market & & & & & & & & \\
\hline 1 & $\begin{array}{l}\text { Do not keep pace with Industry Leaders } \\
\text { outer labor market developments }\end{array}$ & 27.16 & 71.28 & 3 & 5.37 & 59.24 & 7 & $* 2.09$ & 0.04 \\
\hline 2 & $\begin{array}{l}\text { ndustry Administration does not } \\
\text { provide for the external labor market } \\
\text { conditions }\end{array}$ & 22.13 & 68.09 & 6 & *6.87 & 53.26 & 8 & *2.90 & 0.00 \\
\hline 3 & $\begin{array}{l}\text { The lack of job title to allocate } \\
\text { management in the external labor }\end{array}$ & 11.68 & $\mathbf{5 9 . 5 7}$ & 11 & $* 6.68$ & 38.59 & 12 & $* 3.66$ & 0.00 \\
\hline
\end{tabular}




\begin{tabular}{|c|c|c|c|c|c|c|c|c|c|}
\hline & market & & & & & & & & \\
\hline 4 & $\begin{array}{l}\text { Administration specialization does not } \\
\text { fit with the outside labor market needs }\end{array}$ & 17.63 & 65.43 & 9 & 4.77 & 47.83 & 9 & *3.33 & 0.00 \\
\hline 5 & $\begin{array}{l}\text { does not help allocate Administration to } \\
\text { upgrade the professional level for } \\
\text { students to keep up with the external } \\
\text { labor market }\end{array}$ & 14.00 & 63.30 & 10 & 2.89 & 47.83 & 9 & $* 2.87$ & 0.00 \\
\hline 6 & $\begin{array}{l}\text { Inadequate learning outcomes majoring } \\
\text { in administration with the outside labor } \\
\text { market }\end{array}$ & 11.81 & 55.85 & 12 & $* 6.02$ & 46.20 & 11 & 1.90 & 0.06 \\
\hline B & media factors & & & & & & & & \\
\hline 1 & $\begin{array}{l}\text { There is no awareness of the } \\
\text { importance of specialization } \\
\text { management and the nature of work } \\
\text { done }\end{array}$ & $* 47.29$ & 76.06 & 1 & $* 21.15$ & 69.57 & 2 & 1.63 & 0.10 \\
\hline 2 & $\begin{array}{l}\text { here are no media awareness of the } \\
\text { importance of specialization within the } \\
\text { college administration }\end{array}$ & $* 31.59$ & 72.34 & 2 & $* 9.85$ & 62.50 & 4 & 1.95 & 0.05 \\
\hline 3 & $\begin{array}{l}\text { There is no awareness of the } \\
\text { importance of specialty media } \\
\text { management at the College }\end{array}$ & $* 26.17$ & 70.21 & 4 & $* 15.12$ & 64.67 & 3 & 1.27 & 0.20 \\
\hline 4 & $\begin{array}{l}\text { Lack of follow-up of the media to know } \\
\text { the importance of the field of sports } \\
\text { administration }\end{array}$ & $* 25.72$ & 69.68 & 5 & $* 12.80$ & 60.87 & 6 & $* 2.04$ & 0.04 \\
\hline 5 & $\begin{array}{l}\text { Media shows greater importance to the } \\
\text { field of (training, teaching ) }\end{array}$ & $* 20.39$ & 67.55 & 7 & $* 9.85$ & 62.50 & 4 & 0.83 & 0.41 \\
\hline 6 & $\begin{array}{l}\text { Media attention and public culture in } \\
\text { the community develop specialty } \\
\text { (training, teaching ) in the top ranking } \\
\text { of Industry Leaders }\end{array}$ & $* 16.71$ & 66.49 & 8 & *30.80 & 72.28 & 1 & 0.74 & 0.46 \\
\hline
\end{tabular}

$*$ Chi-square significant at the 0.05 level $=5.99 *$ significant where the value of $\mathrm{Z}$ spreadsheet at a level of $0.05=1.96$

Seen from the table (4) of the repetitive and the percentage of statistical and semantic own responses third axis: external factors

(Study1) the presence of significant differences between the responses ranged value of Chi square between (11.68 to 47.29) and the moral values at the 0.05 level, and by consent reached between $(55.85 \%$ to $76.06 \%$ ) also shows the level of responses for each phrase and arrangement of the phrases illustrated from where the most and least approval .

(Study2) the presence of significant differences between the responses except ferries numbers $(1,4,5)$ a ranged value of Chi square between $(2.89$ to 30.80$)$ and by consent reached between ( $38.59 \%$ to $72.28 \%$ ) also shows the level of responses for each phrase The arrangement of the phrases illustrated in terms of the approval of the most and least approval

It is clear from the results these factors affecting the reluctance of students to enroll in Pt_khas Sports Management.

Researcher attribute that to keep up with the importance of specialization of the functions of the external labor market as well as the importance of the media's role in introducing students to the importance of management in the enterprise management and hence the importance of specialization Sports Management .

It can also be distinguished graduate students can be replaced competition in the labor market through:

1. Decisions of multiple academic disciplines with job training

2. Continuing Education to allow the professional to give a new dimension.

3. Forward curriculum and learning environment commensurate with the capabilities of students and Ahtaajthm. (11: 135-140) 
That the separation of educational processes and divergence from the requirements of the labor market developments and the needs of business sectors, organizations and services of skilled human resources and capacity commensurate with the technical condition of the superior prevailing in most of the sectors which are not matched by the curriculum and the content of courses in institutions of higher education. (9:13)

That the media very important role in providing the recipient the public with facts and ideas and the correct information and strengthened, including work on the composition of knowledge and the development of public awareness of the categories with a view to enlighten and help them understand what is going so that his composition of a realistic vision to achieve dealing with the community positively, and that through appropriate media for the dissemination of information material, taking into account the different levels of the receiver to the public. (3:22)

Results agreed with the results of the study are:AbdAsalam Bo zian and Mourad Ben Omara (2011) (4) where suggest that the media played a key role in the enrollment of students to specialize sports, Tawfik Awad Awad (2004) (5), which refers to the importance of organizing media programs to educate students and parents of the importance of the study in the scientific division, creating job opportunities for graduates, especially practical for colleges

It is Seen from the tables $(2,3,4)$ special test Mann-Whitney for comparison between the first and second study in the form phrases and significant differences between the responses except ferries numbers $(1,2,3,4) \mathrm{A},(1,2) \mathrm{b},(1,2,4,6) \mathrm{c}$ of the first-private axis factors related to the student, $(2,4,5,7) \mathrm{A},(1,2,3) \mathrm{b},(1,2,3) \mathrm{c}$ of the second and the private axis factors relating Sports Management and Recreation Department, $(6) A,(1,2,3,5,6) b$ of the third and private axis by external factors, as the $z$ value calculated for these terms it was less than the value of $z$ spreadsheet at the 0.05 level, ranging value $Z$ between (0.00 to 4.39).

And describes own results compared between the first and the second study, there are significant differences between the two studies (and the differences were in favor of the first study)

\section{Conclusions}

- Factors that relate to the student (economic factors - - psychological factors and the mentality of social factors) affect the reluctance of students to enroll in majoring in sports administration, respectively.

- Factors related to sports management and recreation department (faculty - members courses Aldrich- Joined Administration Department) do not affect the reluctance of students to enroll in majoring in sports management.

- External factors (external factors Alma- labor market) affect the reluctance of students to enroll in majoring in sports administration, respectively.

- Discerned the presence of statistically significant differences between the responses of students between the first and second study came in favor of the first study

\section{Recommendations}

- The need to take into account social, economic and psychological factors for the students so as not to affect the turnout of students on specialty management. 
- The need to put the decisions of the administration department in line with developments in the external labor market.

- Coordination between the college and external labor market institutions to provide job opportunities for graduates of the Department of Administration.

- Increasing the rate of spending on education and strengthening appropriate infrastructure to keep up with the outside labor market.

- Raising awareness of the importance of culture and the administration section of the media both internally and externally for students and parents.

- Encourage students to join the administration department by holding regular seminars, workshops and meetings to explain the importance of the administration section.

\section{References}

1- Ahmed Abdul Rahman Ibrahim: Kuwaiti girl's reluctance to exercise various sports activities, magazine theories and Tabulate- Faculty of Physical Education for Boys in Alexandria - number 45.2002

2- Ahmed Higana, Walid Shahin: The reasons for the reluctance of students of the Faculty of Physical Education for the practice of arbitration sports Competitions University of Jordan, Noah University Journal for Research 0.24 folder, Part VIII, 2010

3- Reham Amin Hamza: The role of the media in the sports of thought accepts and resistance to organizational changes to related parties teakwood union, unpublished Master Thesis, Faculty of Physical Education for Girls, Alexandria University, 2007

4- Abdul Salam Bo Xian and Mourad Ben omara: motivated for students of science and techniques of physical and sporting activities on the sports specialization, Faculty of Humanities and Social Sciences, University of Mraah I mean, 2012

5- Awad Tawfiq Awad: His reluctance of students on the scientific division in general secondary education, the National Center for Educational and Scientific Research, Cairo, 2004

6- Eid Mohammed Canaan: Obstacles to the participation of students in the northern Jordan schools and school sports activities , Damascus University Journal , Vol. 26 , p 4.2010

7 - Qassim Mohammed Khuylh: Selection motivated students of the College Sports Sciences at the University of Muta to specialize in track and field games, magazine theories and applications - Faculty of Physical Education for Boys in Alexandria - number 58-2006 8 - Kamal al-Din Darwish, Mohamed Sobhi Hassanein: Quality and globalization in the sports business management using innovative management methods, Volume I, Dar Al Arab Thought, Cairo.2004

9 - Mohamed Sayed Abu Saud: The development of education and its role in building the knowledge economy, the First International - Conference of e-learning and distance learning, learning industry for the future Riyadh, in March . 2009

10- He Emirates Center for Strategic Studies and Research: Manumit human resources in the knowledge-based economy, i 1, Abu Dhabi, United Arab Emirates, 2004

11- He Emirates Center for Strategic Studies and Research: institutions of higher education management under the Knowledge Economy, 1st Floor, Abu Dhabi, United Arab Emirates, 2009

12- Mustafa Yusuf Kaafy: E-learning and knowledge-based economy, Dar Russian Foundation for printing, publishing and distribution, Damascus, Syria, 2009 
13- Muwafaq Ayoub Mohsen: The reasons for lack of interest by some university students to review the university libraries, No. 53, Alfath Magazine, 2013

14- Nihad Battikhi: The reasons for the reluctance of students of the Faculty of Physical Education for the practice of sport table tennis in the Faculty of Physical Education, Journal of theories and applications - Faculty of Physical Education for Boys in Alexandria - number 56-2005

15- Noha Mohammed Mahmud: The reasons for the reluctance of first-grade secondary students to enroll in public schools branch scientific Gaza province and ways to reduce them, unpublished Master Thesis, the Islamic University of Gaza, 2011 16- Ac. Kgoz, Firat: A study on Teacher characteristics and their effects on student's attitudes, Vole. September, 2, 2005

17- Armstrong, Ketra L: Race and sport consumption Motivations A preliminary Investigation of aback consumers, sport Motivation seal; Journal of sport behavior; Dec 2002, Vole. 25 Issue 4, p309

18- Ion pârgaru, rodica gherghina, ioana duca: The role of education in the knowledgebased society during the economic crisis, annals universitatis opulence's series oeconomica, 11.2009

19- Wang,C.K.Joh \& Biddle,Stuart J.H: Intrinsic Motivation Towards sports in sing aporean students: The Role of sport Ability Beliefs Journal of Health Psychology, Vole 8 Issues5,P 515 "; sep 2003 